\title{
Comparative genome analysis of Streptococcus infantarius subsp. infantarius CJ18, an African fermented camel milk isolate with adaptations to dairy environment
}

\author{
Christoph Jans, Rainer Follador, Mira Hochstrasser, Christophe Lacroix, Leo Meile ${ }^{*}$ and Marc J A Stevens
}

\begin{abstract}
Background: Streptococcus infantarius subsp. infantarius (Sii) belongs to the Streptococcus bovis/Streptococcus equinus complex associated with several human and animal infections. Sii is a predominant bacterium in spontaneously fermented milk products in Africa. The genome sequence of Sii strain CJ18 was compared with that of other Streptococcus species to identify dairy adaptations including genome decay such as in Streptococcus thermophilus, traits for its competitiveness in spontaneous milk fermentation and to assess potential health risks for consumers.

Results: The genome of Sii CJ18 harbors several unique regions in comparison to Sii ATCC BAA-102 ${ }^{\top}$, among others an enlarged exo- and capsular polysaccharide operon; Streptococcus thermophilus-associated genes; a region containing metabolic and hypothetical genes mostly unique to CJ18 and the dairy isolate Streptococcus gallolyticus subsp. macedonicus; and a second oligopeptide transport operon. Dairy adaptations in CJ18 are reflected by a high percentage of pseudogenes (4.9\%) representing genome decay which includes the inactivation of the lactose phosphotransferase system (IacIIABC) by multiple transposases integration. The presence of lacS and lacZ genes is the major dairy adaptation affecting lactose metabolism pathways also due to the disruption of lacllABC.

We constructed mutant strains of lacS, lacZ and laclIABC and analyzed the resulting strains of CJ18 to confirm the redirection of lactose metabolism via LacS and LacZ.

Natural competence genes are conserved in both Sii strains, but CJ18 contains a lower number of CRISPR spacers which indicates a reduced defense capability against alien DNA. No classical streptococcal virulence factors were detected in both Sii strains apart from those involved in adhesion which should be considered niche factors. Sii-specific virulence factors are not described. Several Sii-specific regions encoding uncharacterized proteins provide new leads for virulence analyses and investigation of the unclear association of dairy and clinical Sii with human diseases.
\end{abstract}

Conclusions: The genome of the African dairy isolate Sii CJ18 clearly differs from the human isolate ATCC BAA-102 ${ }^{\top}$. CJ18 possesses a high natural competence predisposition likely explaining the enlarged genome. Metabolic adaptations to the dairy environment are evident and especially lactose uptake corresponds to $S$. thermophilus. Genome decay is not as advanced as in S. thermophilus (10-19\%) possibly due to a shorter history in dairy fermentations.

Keywords: Streptococcus infantarius, Streptococcus bovis/Streptococcus equinus complex, Streptococcus thermophilus, Streptococcus gallolyticus subsp. macedonicus, Dairy fermentation, Lactose metabolism, Africa, Camel, Health risk, Streptococcus virulence factors

\footnotetext{
* Correspondence: leo.meile@hest.ethz.ch

Laboratory of Food Biotechnology, Institute of Food, Nutrition and Health, Schmelzbergstrasse 7, ETH Zurich, Zurich, CH 8092, Switzerland
} 


\section{Background}

The putative pathogen Streptococcus infantarius subsp. infantarius (Sii) is a lactic acid bacterium (LAB) commonly associated with the gastrointestinal tract of animals and humans [1]. Additionally, Sii has been isolated from dairy products, feces (including the type strain ATCC BAA- $102^{\mathrm{T}}$ and isogenetic strain CCUG $43820^{\mathrm{T}}$ ), human blood $(\mathrm{n}=3)$ and human endocarditis $(\mathrm{n}=3)$ [2-5]. Recently, it was identified as the predominant species in several spontaneously fermented African dairy products such as suusac, gariss and fènè [2,5-7] and in the Mexican fermented maize beverage pozol [8]. Sii belongs to the Lancefield group D Streptococcus bovis/ Streptococcus equinus complex (SBSEC) which comprises the species S. bovis, S. equinus, Streptococcus lutetiensis (known as Streptococcus infantarius subsp. coli), Streptococcus gallolyticus subsp. gallolyticus (formerly S. bovis biotype I), Streptococcus gallolyticus subsp. macedonicus, Streptococcus gallolyticus subsp. pasteurianus and Streptococcus alactolyticus $[3,4,9]$.

The SBSEC is commonly associated with many infectious diseases such as bacteremia, endocarditis and bloat [1]. Moreover, some members of the group, especially S. gallolyticus subsp. gallolyticus, are suspected to play a role in colonic cancer development [10,11], partly associated to increasing mRNA levels of IL-1, IL-8 and COX-2 in colorectal tissue, which contribute to inflammation caused tumor development [12]. Because of the high risk association of mainly S. gallolyticus subsp. gallolyticus with infectious diseases and cancer, research on virulence within the SBSEC group has largely focused on this species [12-16]. Virulence factors such as fibrinogen binding factor FimB, glucosyltransferase Gtf and pilus subunit B PilB have been identified in several SBSEC members [16-19]. Additionally, potential virulence factors such as adhesion proteins have been shown e.g. the surface protein histone-like protein A (HlpA), the "adhesion to collagen of the S. bovis group" (Acb) and "S. bovis group surface protein" (Sbs) $[14,20]$. However, many of these factors seem to be necessary for survival of SBSEC in the gastrointestinal tract and should therefore be considered as niche factors [21].

The pathogenicity of Sii is less elucidated. Potential pro-inflammatory proteins were detected in Sii and the species is also associated with non-colonic cancer [22,23]. In parallel to S. gallolyticus subsp. gallolyticus, a Sii strain isolated from feces of an infected baby was able to translocate across a polarized epithelial monolayer of Caco-2 cells, a property which potentially facilitates infection [24]. This ability was so far only demonstrated for a single Sii strain of clinical and not of food origin. In a recent and broad clinical study on $58 \mathrm{~S}$. bovis strains, only the subspecies S. infantarius subsp. coli $(\mathrm{n}=17)$, but not Sii, was isolated from blood of infected patients among 29
S. gallolyticus subsp. gallolyticus and 12 S. gallolyticus subsp. pasteurianus [10]. This suggests only a minor role of Sii in infectious diseases. Nevertheless, the predominance of Sii in African food fermentations [2-5] and, as a consequence, the ingestion of high amounts of viable cells of this species by the consumer demands further research to elucidate any potential pathogenic traits of this SBSEC member and possibly diverge dairy from clinical isolates.

Streptococcus thermophilus is the only streptococcal species recommended by the qualified presumption of safety (QPS) for use in fermented food products [25]. It displays an adaptation to the milk environment that is characterized by genome reduction, gene decay and loss of function, which is reflected by the high abundance of pseudogenes in all sequenced S. thermophilus genomes $[26,27]$. Genome reduction through loss or inactivation of virulence factors and long history of use contributed to the recognition of $S$. thermophilus by QPS, despite its close genetic relationship to the SBSEC [25-29]. Interestingly, Streptococcus macedonicus ACA-DC 198 (designated S. gallolyticus subsp. macedonicus in this study according to [3]), a Greek cheese isolate, displayed comparable genome decay to $S$. thermophilus and could indicate parallel evolutionary adaptation to the dairy environment in other members of the SBSEC and important contributions of certain members of the SBSEC to dairy fermentations in Europe [30].

The predominance and probably exclusive habitat of the African Sii variants in dairy fermentations suggests adaptation to the dairy environment similar to $S$. thermophilus $[2,7]$. This predominance seems directly related to the presence of a gal-lac operon in the African variant of Sii [7], a feature that is absent in other members of the SBSEC. Furthermore, African strains display a lactose fermentation pattern paralleling that of S. thermophilus [7]. The high prevalence of bacteriocin producers among African Sii isolates likely contributes to the predominance of Sii in African dairy fermentations [2].

In this work, we present the complete genome sequence of Sii CJ18 isolated as representative predominant strain from spontaneously fermented camel milk suusac from Kenya at over $10^{8} \mathrm{CFU} \mathrm{mL}{ }^{-1}$. CJ18 does not produce bacteriocin-like inhibitory substances [2]. It was selected for genome sequencing due to genetic and metabolic evidence of a lactose fermentation pattern similar to $S$. thermophilus after studying of 3 different African Sii isolates [7]. A genomic comparison of strain CJ18 to other pathogenic and non-pathogenic streptococci was performed in order to identify dairy adaptations and potential virulence factors in CJ18. Our study provides new insight into streptococcal evolution in the previously untouched ecosystem of dairy fermentations in Africa and provides new insight on safety and 
occurrence of horizontal gene transfer (HGT) of streptococci in food fermentations.

\section{Results}

\section{General genome properties}

The genome of Sii CJ18 consists of a 1,988,420-bp circular molecule encoding 2050 genes of which 1867 encode for proteins [GenBank:CP003295, GenBank:CP003296] (Table 1) [31]. Comparison of genes with their homologues in other streptococcal genomes, resulted in detection of 97 $(4.9 \%)$ genes that carry a deletion, insertion or premature stop, and that were therefore assigned as pseudogenes. Additionally, 19,829 bp of plasmid related DNA, designated pSICJ18-1, providing 35 coding DNA sequences (CDS) with only limited similarity to SBSEC sequences were detected. The nucleotide sequence (96-100\% identity) and $\mathrm{G}+\mathrm{C}$ mol\%-content of 30 out of $35 \mathrm{CDS}$ suggest a lactococcal origin [Additional file 1].

The origin of the genome of CJ18 was determined upstream of the $d n a A$ gene and corresponds to the switch in GC-skew (Figure 1). However, a shift towards the 5 o'clock position was detected for the terminus position, as is reflected by a switch in the GC-skew and in the CDSdensity on the forward and reverse strand (Figure 1), a feature also observed in S. gallolyticus subsp. gallolyticus ATCC 43143 and S. gallolyticus subsp. pasteurianus ATCC 43144 [32].

The complete genome sequence was used to confirm the taxonomy of CJ18 through alignment and subsequent phylogenetic analysis using $16 \mathrm{~S}$ rRNA and eight typical streptococcal genes (groEL, gyrB, recA, recN, rpoB, secA, $\sec Y$ and $\operatorname{sod} A$ ). All genes clearly positioned CJ18 within the SBSEC on the same branch as its closest relative Sii ATCC-BAA- $102^{\mathrm{T}}$ (Figure 2, tree only shown for groEL). The highest bootstrap percentages were obtained for trees based on $g r o E L, r e c N$ and $\sec Y$ sequences (data not shown).

\section{Comparison of CJ18 to ATCC BAA- $102^{\top}$ and other SBSEC strains}

The draft genome sequence of the Sii ATCC BAA-102 ${ }^{\mathrm{T}}$ type strain was used for a comparison to the African isolate CJ18. An in silico hybridization revealed that the organization of loci was highly conserved between CJ18 and ATCC BAA-102 ${ }^{\mathrm{T}}$ (Figure 3) and to the closely related species S. gallolyticus subsp. macedonicus and S. gallolyticus subsp. gallolyticus, albeit at a lesser degree [Additional file 2]. The genome of CJ18 is $37 \mathrm{~kb}$ larger than that of ATCC BAA- $102^{\mathrm{T}}$ and harbors a number of variable regions and insertions compared to other streptococci, designated R1-R15 (Figure 4 and [Additional file 1]). The major variable regions comprise phage-related proteins (R4, $34.2 \mathrm{~kb}$ ), proteins with high sequence identity to $S$. thermophilus (R6, $25.6 \mathrm{~kb}$ ) and a cluster of metabolic and hypothetical proteins specific for CJ18 (R9, $26.1 \mathrm{~kb})$.
Interestingly, R14 comprises many hypothetical proteins shared to the largest extent with the Greek cheese isolate $S$. gallolyticus subsp. macedonicus ACA-DC 198 (R14, $52.5 \mathrm{~kb}$ ) and second to ATCC BAA-102 ${ }^{\mathrm{T}}$. This suggests a closer relationship among these SBSEC strains compared to the other strains used in genome analysis and might possibly even be related to the dairy origin. Remarkably, variable regions often possess a distinct base-deviation index in CJ18, indicating recent evolutionary origin due to little advanced amelioration (Figure 4).

For 179 CDSs in CJ18, no homologous CDS were detected in ATCC BAA-102 ${ }^{\mathrm{T}}$. However, homologous CDS were detected in other streptococci for 103 of them, whereas for the other 76 CDS no significant hits were found in related strains [Additional file 1] (Table 2). The reverse comparison revealed 310 CDS from ATCC BAA-102 ${ }^{\mathrm{T}}$ without orthologous CDS in CJ18, 97 of which encoded for hypothetical proteins [Additional file 1]. This comparison of the African dairy isolate CJ18 to the type strain reveals a high similarity in gene content and organisation. However, there are some remarkable differences in gene content suggesting a distinct evolution of the two strains.

\section{Carbohydrate metabolism}

Carbohydrate transport in bacteria is frequently mediated via phosphotransferase systems (PTSs). PTS encoding operons were detected in both Sii strains for the uptake of $\beta$-glucosides, lactose, fructose/mannose, fructose, sucrose, maltose/glucose and cellobiose. Such a wide variety of transport systems is often observed in GI-tract associated microbes [50]. Remarkably, the lactose PTS gene locus in CJ18 (Sinf_0190-0195) is interrupted by three transposases, two truncating the $\beta$-glucoside $\mathrm{Bgl}$ operon antiterminator upstream of the PTS genes and one within the 6-phospho- $\beta$-galactosidase downstream of the PTS genes, suggesting that the lactose PTS in CJ18 is not involved anymore in lactose utilization.

Genes involved in galactose utilization in CJ18 are organized in the operon galRKTE2 operon (Sinf_0205-0208). However, compared to ATCC BAA-102 ${ }^{\mathrm{T}}$, CJ18 harbors an additional gal-lac operon comprising genes galT(truncated)/galE1M/lacSZ (Sinf_0939-Sinf_0935) with high sequence identity (>91\%) to S. thermophilus [7] and localized in region R6 [Additional file 3]. Also genes in the proximity of this gal-lac operon display high sequence identity to $S$. thermophilus, comprising among others the putative virulence gene encoding exfoliative toxin B (Sinf_0933), an acyl-CoA dehydrogenase (Sinf_0932) and a macrophage infectivity potentiator (Sinf_0931) [Additional file 1] [Additional file 3]. Although the high sequence conservation indicates an S. thermophilus origin, the sequential order of genes is only conserved in the gal-lac operon. Mainly non-conserved DNA sequences were localized downstream of the gal-lac operon and the truncated galT. 
Table 1 General features of the Sii CJ18 genome and other sequenced genomes of streptococci

\begin{tabular}{|c|c|c|c|c|c|c|c|c|c|c|c|c|c|}
\hline & \multicolumn{2}{|c|}{$\begin{array}{l}\text { S. infantarius subsp. } \\
\text { infantarius }\end{array}$} & \multicolumn{3}{|c|}{ S. gallolyticus subsp. gallolyticus } & \multirow{2}{*}{$\begin{array}{l}\text { S. gallolyticus } \\
\text { subsp. } \\
\text { macedonicus } \\
\text { ACA-DC } 198\end{array}$} & \multirow{2}{*}{$\begin{array}{l}\text { S. gallolyticus } \\
\text { subsp. } \\
\text { pasteurianus } \\
\text { ATCC } 43144\end{array}$} & \multirow{2}{*}{$\begin{array}{c}\text { S. } \\
\text { agalactiae } \\
2603 \mathrm{~V} / \mathrm{R}\end{array}$} & \multirow{2}{*}{$\begin{array}{c}\text { S. } \\
\text { pyogenes } \\
\text { M1 GAS }\end{array}$} & \multirow{2}{*}{$\begin{array}{c}\text { S. } \\
\text { pneumoniae } \\
\text { D39 }\end{array}$} & \multicolumn{3}{|c|}{ S. thermophilus } \\
\hline & CJ18 & $\begin{array}{c}\text { ATCC } \\
\text { BAA-102 }^{\top}\end{array}$ & ATCC 43143 & $\begin{array}{c}\text { ATCC } \\
\text { BAA-2069 }\end{array}$ & UCN34 & & & & & & LMD-9 & $\begin{array}{l}\text { CNRZ } \\
1066\end{array}$ & $\begin{array}{c}\text { LMG } \\
18311\end{array}$ \\
\hline length (bp) & $\begin{array}{c}1,988,420+ \\
19,829 \\
\text { pSICJ18-1 }\end{array}$ & $1,938,634$ & $2,362,241$ & $2,356,444$ & $2,350,911$ & $\begin{array}{c}2,130,034+12,728 \\
\text { pSMA198 }\end{array}$ & $2,100,077$ & $2,160,267$ & $1,852,441$ & $2,046,115$ & $1,856,368$ & $1,796,226$ & $1,796,846$ \\
\hline $\mathrm{G}+\mathrm{C}(\mathrm{mol} \%)$ & 37.6 & 37.6 & 37.5 & 37.6 & 37.6 & 37.6 & 37.4 & 35.6 & 38.5 & 39.7 & 39.1 & 39.1 & 39.1 \\
\hline genes & $\begin{array}{l}2050+35 \\
\text { pSICJ18-1 }\end{array}$ & 1988 & 2371 & $\begin{array}{c}2410+21 \\
\text { pSGG1 }\end{array}$ & 2349 & $\begin{array}{l}2280+17 \\
\text { pSMA198 }\end{array}$ & 2102 & 2276 & 1810 & 2069 & $\begin{array}{c}2002+4 \\
\text { Plsm1 + } 2 \\
\text { Plsm } 2\end{array}$ & 2000 & 1973 \\
\hline $\begin{array}{l}\text { pseudogenes/ } \\
\text { truncated } \\
\text { proteins }(\%)^{b)}\end{array}$ & $97(4.9 \%)$ & $n / a^{a)}$ & $49(2.1 \%)$ & 0 & $37(1.6 \%)$ & $215(9.8 \%)$ & $157(7.9 \%)$ & 0 & $35(2.0 \%)$ & $82(4.1 \%)$ & $\begin{array}{c}206 \\
(10.8 \%)\end{array}$ & $\sim 19 \%$ & $\sim 19 \%$ \\
\hline $\begin{array}{l}\text { protein (non } \\
\text { tRNA/rRNA) }\end{array}$ & 1867 & & 2246 & 2309 & 2223 & 1977 & 1869 & 2124 & 1696 & 1914 & 1709 & 1915 & 1888 \\
\hline tRNA genes & 68 & $46^{c)}$ & 60 & 80 & 71 & 70 & 61 & 80 & 60 & 58 & 67 & 67 & 67 \\
\hline rRNA genes & 18 & $8^{c)}$ & 15 & 21 & 18 & 17 & 15 & 21 & 18 & 12 & 19 & 18 & 18 \\
\hline source & $\begin{array}{l}\text { fermented } \\
\text { camel milk } \\
\text { suusac [31] }\end{array}$ & $\begin{array}{l}\text { baby feces } \\
\text { (HMP) }\end{array}$ & $\begin{array}{l}\text { human clinical } \\
\text { specimen, } \\
\text { blood [32] }\end{array}$ & $\begin{array}{l}\text { human clinical } \\
\text { specimen, } \\
\text { blood [33] }\end{array}$ & $\begin{array}{c}\text { human clinical } \\
\text { specimen, } \\
\text { blood [13] }\end{array}$ & $\begin{array}{l}\text { Greek Kasseri } \\
\text { cheese [30] }\end{array}$ & $\begin{array}{l}\text { human clinical } \\
\text { specimen, } \\
\text { blood [32] }\end{array}$ & $\begin{array}{c}\text { human } \\
\text { clinical } \\
\text { specimen [34] }\end{array}$ & $\begin{array}{c}\text { human } \\
\text { clinical } \\
\text { specimen [35] }\end{array}$ & $\begin{array}{c}\text { human } \\
\text { clinical } \\
\text { specimen [36] }\end{array}$ & $\begin{array}{c}\text { yogurt } \\
{[27]}\end{array}$ & $\begin{array}{c}\text { yogurt } \\
{[26]}\end{array}$ & $\begin{array}{c}\text { yogurt } \\
{[26]}\end{array}$ \\
\hline
\end{tabular}






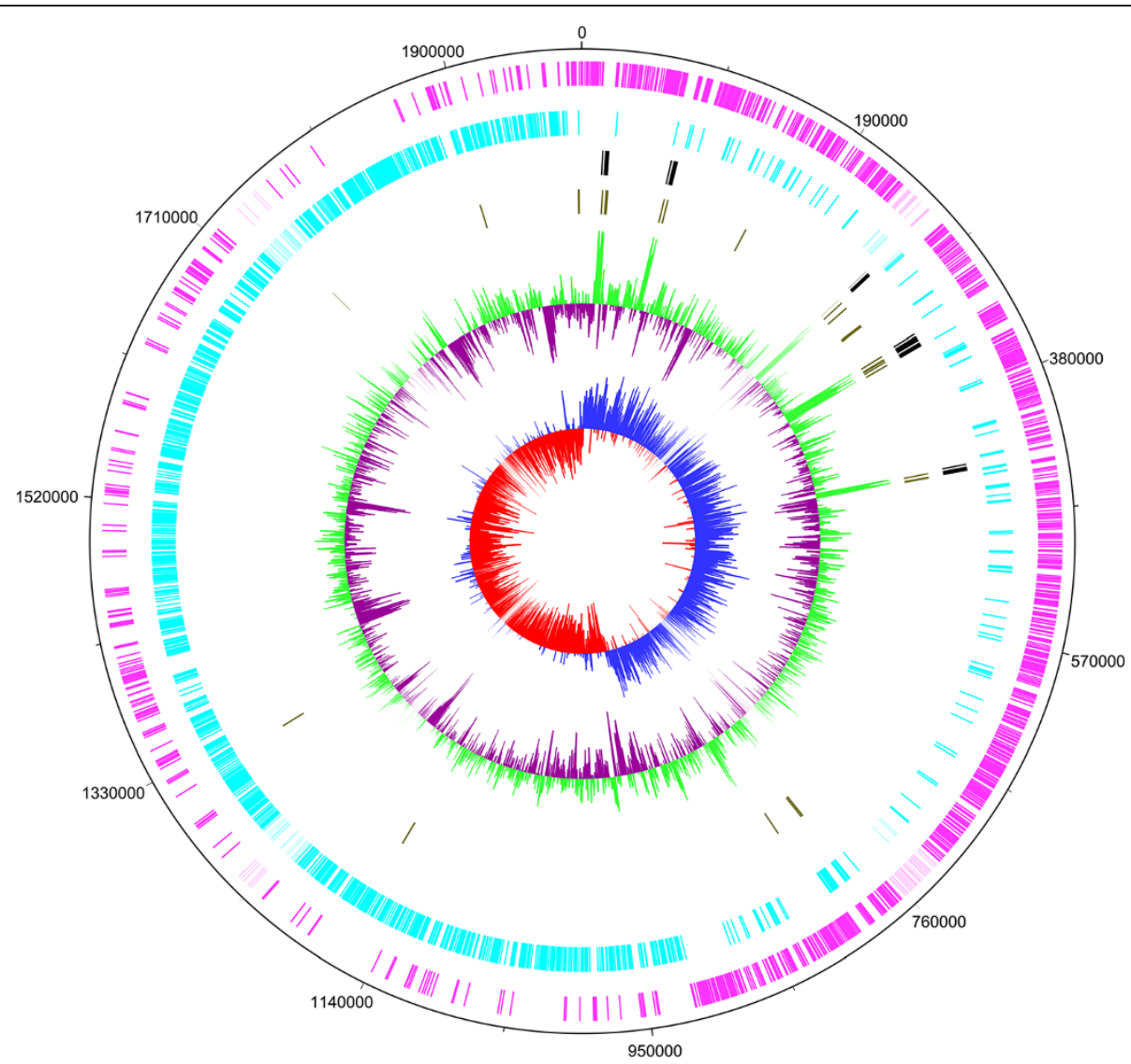

Figure 1 Circular genome of Sii CJ18. The inner most circle shows the GC-skew of higher (blue) and lower (red) than average followed by the GC-content with higher (green) and lower (dark purple) than average. The third (olive green) and fourth circle (black) display tRNA and rRNA, respectively. The two outermost circles indicate the position of coding sequences on the forward (pink) or reverse (ice blue) strand.

Surprisingly, a second lacS (Sinf_1514) was detected in both Sii strains not adjacent to either the gal or gal-lac operon. This second LacS displays $98.9 \%$ amino acid sequence identity between the two $S$. infantarius strains and lower identity $(60 \%)$ to the S. thermophilus-like LacS (Sinf_0936). The physiological role of this second LacS is unknown.

To elucidate the role of two lactose transport systems in lactose metabolism of CJ18, knock-out (KO) strains were constructed in the lactose translocater lacS (Sinf_ 0936), the $\beta$-galactosidase lacZ (Sinf_0935) and the permease unit of the lactose PTS encoding gene lacIIC (Sinf_0192) using a single-cross-over strategy (Table 3). Phenotypes of $\mathrm{KO}$ strains were confirmed on $\mathrm{BHI} / \mathrm{X}$ Gal/IPTG agar media yielding blue colonies for $\mathrm{CJ} 18^{\mathrm{WT}}$

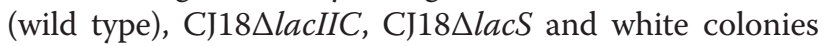
for CJ18 lacZ. This indicates no polar effects of lacS disruption on the expression of the lac $Z$ gene downstream of lacS [Additional file 4]. The wild type CJ18 and its mutant derivatives CJ18 1 lacIIC, CJ18 lacS and CJ18 $\triangle$ lacZ grew similarly in control medium containing glucose as sole carbon source [Additional file 5]. When grown with lactose as sole carbon source, CJ18 1 lacIIC displayed a similar growth pattern as the wild type CJ18 (Figure 5), indicating that lactose uptake in CJ18 is not mediated by the lactose PTS. Strains disrupted in genes of the gal-lac operon, CJ18 lacS and CJ18 lacZ had clearly an impaired growth rate on lactose (Figure 5). The growth characteristics of the mutant strains CJ18 LlacS and CJ18 $\Delta$ lacZ on lactose show that lactose is utilized in CJ18 via uptake by LacS and subsequently cleaved by LacZ with a similar mechanism to the lactose metabolism of $S$. thermophilus.

\section{Additional features related to dairy environment}

Oligopeptide transporters are important during growth in milk for the uptake of peptides and amino acids [54,55]. Similar to ATCC BAA-102 ${ }^{\mathrm{T}}$, CJ18 possesses an OppABCDF peptide transport system (Sinf_0305-0309) but the genome of CJ18 encodes two additional OppA (Sinf_1225 and Sinf_1226) and, remarkably, a second OppABCDF encoding operon (Sinf_1825-1821, region R15, Figure 4) with high sequence identity to Streptococcus equi, Streptococcus pyogenes or Streptococcus gordonii [Additional file 1]. Single 




amino acid transport systems are conserved in both strains and in contrast to $S$. thermophilus strains, no reduction in amino acid biosynthesis pathways was observed for CJ18. Both S. infantarius strains encode apparent complete pathways, such as histidine and glutamate biosynthesis or arginine catabolism (CJ18).

Capsular polysaccharides (CPS) and exopolysaccharides (EPS) are involved in the adhesion properties of bacteria through biofilm formation and serve as a defense mechanism against immune responses [56,57]. Furthermore, EPS may contribute to the texture of many dairy products. CJ18 and ATCC BAA- $102^{\mathrm{T}}$ both possess a conserved $5-\mathrm{kb}$ operon for EPS biosynthesis. The genetic organization downstream of this cluster differs between the two $S$. infantarius strains. CJ18 harbors a number of additional EPS and CPS biosynthesis genes (R3, Figure 4) that share highest protein sequence identities with proteins of species outside of the SBSEC. Remarkably, the same region in CJ18 contains wefC encoding a receptor polysaccharide phosphotransferase, also termed stealth protein. This gene is absent in ATCC BAA- $102^{\mathrm{T}}$ and displays high sequence homology to CpsJ of S. thermophilus (99\%). Based on in silico analysis it was hypothesized to be involved in protection from the host immune system [58]. The presence of a high variety of EPS genes could be caused by selection during suusac manufacturing, but could also imply an additional virulence risk if a strain displays further virulence factors for e.g. invasion, infection or toxin production.

\section{Adhesion and other virulence factors}

Adhesion of bacteria to surfaces is influenced by many factors such as EPS or CPS production as mentioned above, but also certain specific proteins. A fibronectin binding protein $\mathrm{Fpb}$ involved with adhesion to fibronectin and fibrinogen is present in both ATCC BAA- $102^{\mathrm{T}}$ and CJ18. Streptococcus bovis group surface proteins (Sbs) are also involved in adhesion and found in both CJ18 (7 genes) and in ATCC BAA- $102^{\mathrm{T}}$ (8 genes). Five of these Sbs are organized in a $13.7-\mathrm{kb}$ region (R13, Figure 4) in CJ18 comprising a truncated Sbs 13 (collagen binding protein, Sinf_1737), an LPXTG-specific A/C-type sortase (Sinf_ 1742), Sbs14 (autotransporter adhesion/cell wall anchored 


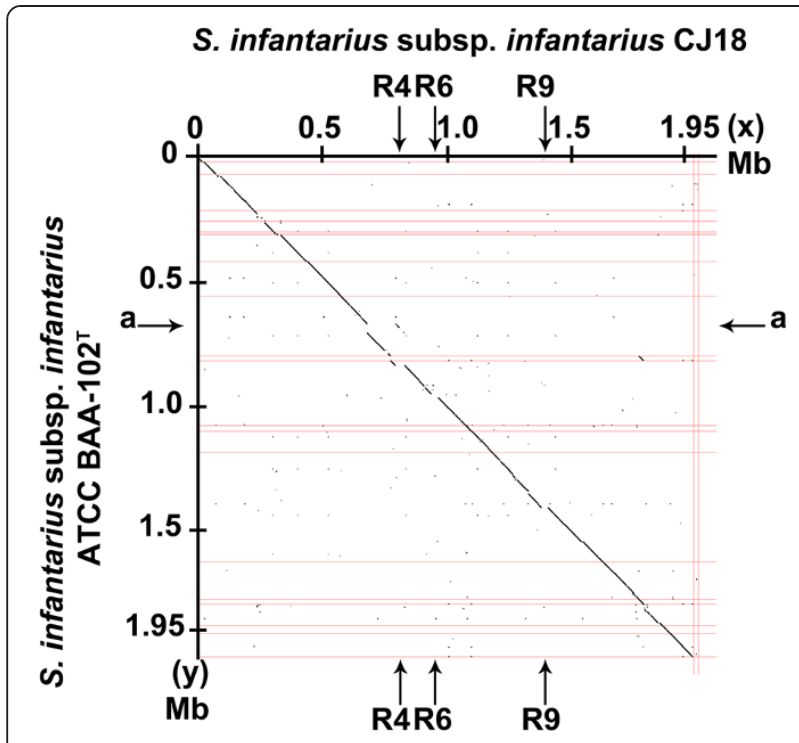

Figure 3 Synteny plot of genomes Sii CJ18 (x) vs. Sii ATCC BAA-102 ${ }^{\top}(\mathbf{y})$. Both genomes of the Sii strains display a high degree of conservation indicated by the alignment near the diagonal line. Major insertion sites can be identified as R4 (34.2 kb) consisting largely of phage-related genes; R6 (25.6 kb) encompassing a 13.2-kb S. thermophilus-gene cluster comprising the additional gal-lac operon; and R9 (26.1 kb) containing among others an HTH-type transcriptional regulator Rgg, primosomal protein $\mathrm{N}^{\prime}$ (replication factor Y) - superfamily II helicase, an FtsK/SpolllE family protein and a conjugal transfer protein. The major gap a (34.6 kb) in ATCC BAA-102 ${ }^{\top}$ corresponds to a phage region.

protein, Sinf_1743) and Sbs15 (ribonuclease G and E/peptidoglycan linked protein, Sinf_1744). This region upstream of Sbs 13 is conserved in CJ18 and ATCC BAA- $102^{\mathrm{T}}$, the dairy isolate $S$. gallolyticus subsp. macedonicus ACA-DC 198 and other S. gallolyticus strains. The presence of Sbs4 and Sbs9 suggests that certain adhesion factors are shared among SBSEC as commensal inhabitants of gastrointestinal tracts and detected also in the dairy strain S. thermophilus LMG18311. These factors might only contribute to virulence if further factors for invasion or toxin production are present as well. Other adhesion factors like S. bovis adhesion proteins $(\mathrm{Acb})$ or others from non-SBSEC origin, such as FimA and FimB, are not present in both Sii strains.

A hemolysin III protein highly identical to that of the S. gallolyticus group including S. gallolyticus subsp. macedonicus ACA-DC 198 (91\%) as well as that of S. thermophilus LMD-9 (80\%) is encoded in both Sii strains. No defibrinated sheep blood hemolysing activity was detected for both strains. A direct implication of virulence from the presence of a hemolysin gene except streptolysin $\mathrm{O}$ is not yet established for streptococci [59].

Typical virulence factors of non-SBSEC-members $S$. pyogenes, S. agalactiae and S. pneumoniae had been used for the safety evaluation of S. thermophilus [26]. Some of these virulence factors were previously found in $S$. gallolyticus UCN34 such as ssaB/scaA/psaA (locus tag Gallo_2047), pilB (Gallo_0087), gtfbC (Gallo_1055), atlA (Gallo_1368) [32] and used to screen strains in this study. $s s a B / s c a A / p s a A$ was not detected in Sii strains whereas atlA displayed a lower protein sequence identity in CJ18 (49\%) compared to the cheese isolate S. gallolyticus subsp. macedonicus ACA-DC 198 (91\%). Pro-inflammatory proteins [23] were detected in both Sii strains but also in $S$. thermophilus since they encode basic metabolic functions. Finally, comparison with an in silico genome containing antimicrobial resistance and virulence factor genes $[37,60]$ did not result in significant hits with any typical or concerning streptococcal virulence factors for both CJ18 and ATCC BAA- $102^{\mathrm{T}}$.

\section{Natural competence}

Several regions potentially involved in natural competence were detected in both $S$. infantarius strains. These include a competence operon (comGA/GB/GC/GD/GE/GF/GG), separate competence genes and a CoiA encoding gene involved in DNA uptake. Furthermore, a CJ18-unique restriction endonuclease and methylase were detected in region R5 (Figure 4). In addition, both strains contain recombination proteins like RecA, the Rossman fold nucleotide-binding protein Smf/DprA and the single-strand DNA binding protein SsbB [61,62]. The organization and mechanism of the competence-related genes (com X/sigX and comS promoters) seems to be conserved in both ATCC BAA- $102^{\mathrm{T}}$ and CJ18 as well as most other streptococci [63]. However, CJ18 harbors an additional conjugal transfer protein (Sinf_1366 region R9, Figure 3) with high protein sequence identity (82\%) to S. thermophilus variant, suggesting a potentially increased capability for DNA uptake compared to ATCC BAA- $102^{\mathrm{T}}$.

This is further supported by the apparent reduced activity of Clustered Regularly Interspaced Short Palindromic Repeats (CRISPRs) and CRISPR associated genes (cas) forming the CRISPR/Cas system for defense against foreign DNA [64]. Both CJ18 and ATCC BAA-102 ${ }^{\mathrm{T}}$ harbor single copies of $\operatorname{csn} 2$, cas 1 and cas 2 in region R8 (Figure 4). But remarkably, the CJ18 proteins Csn2, Cas1 and Cas2 had higher identity (88-93\%) with the corresponding proteins in S. gallolyticus, S. bovis and S. equinus than with ATCC BAA-102 ${ }^{\mathrm{T}}$. A CRISPR array comprises a leader sequence followed by identical repeated DNA sequences intersected by highly variable spacer sequences. CJ18 comprises a CRISPR/Cas section with 9 spacers whereas ATCC BAA- $102^{\mathrm{T}}$ harbors 29 spacers. The relative low number of CRISPR spacers predicts a lower CRISPR activity in CJ18 and thus a decreased protection against foreign DNA.

No DNA sequence identity was detected between any of the spacers. This indicates strain dependent Cas/CRISPR activity in S. infantarius also reported for S. thermophilus strains [65]. 


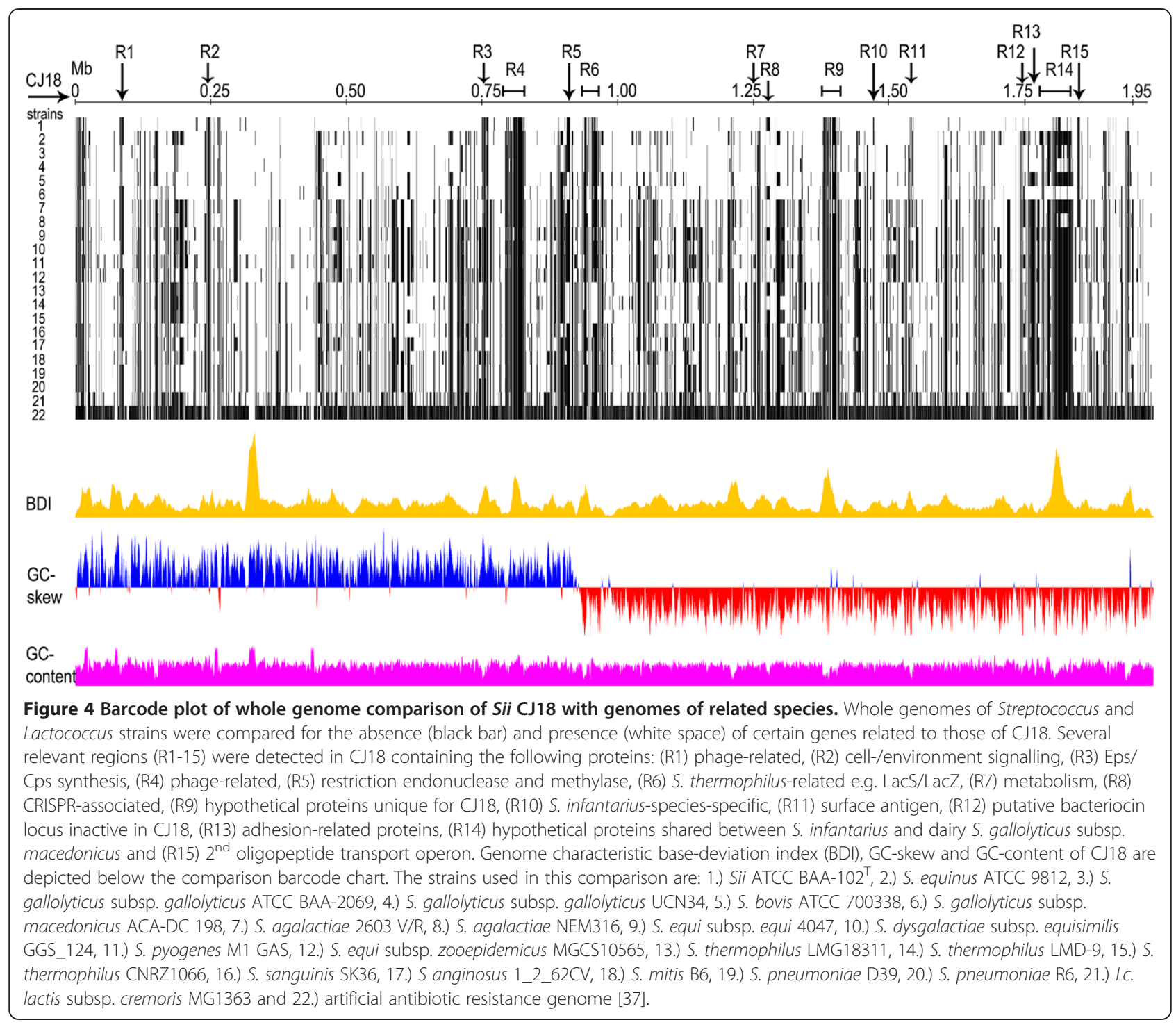

\section{Other features in the $\mathrm{CJ} 18$ genome}

Production of bacteriocins is widely distributed among streptococci [66]. S. infantarius CJ18, ATCC BAA-102 ${ }^{\mathrm{T}}$ and also LP90 (Table 2) possess a highly conserved bacteriocin ABC-transporter accessory protein InfAE-acc, shared also with S. gallolyticus strains (competence-stimulating peptide ABC transporter-permease ComB Sinf_1732) and the bacteriocin $\mathrm{ABC}$-transporter InfAE-ABC (competencestimulating peptide $\mathrm{ABC}$ transporter ATP-binding protein ComA Sinf_1731) located in region R12. Putative bacteriocin encoding genes were detected in ATCC BAA- $102^{\mathrm{T}}$, but none in strain $\mathrm{CJ} 18$, which confirms previous findings on its inability to produce bacteriocin-like inhibitory substances [2].

Unique phage-related genes are located in CJ18 in regions R1 and R4 (Figure 4). CJ18 and ATCC BAA102 ${ }^{\mathrm{T}}$ harbor both four and five phage integrase genes, respectively. However, only one of them (Sinf_0428) has a homologous gene in ATCC BAA- $102^{\mathrm{T}}$ (100\% nucleotide identity), indicating possible distant relationship between these strains.

Remarkable differences between both $S$. infantarius strains and their closest related species within the SBSEC S. gallolyticus UCN34 (Figure 2) were a reduction in carbohydrate transport systems, e.g. the absence of trehalose and mannitol transporting and degrading enzymes which play a role in maintenance in the bovine rumen. This indicates a generally lower adaptation of $S$. infantarius to the bovine rumen as a habitat compared to S. gallolyticus and provides additional evidence to separate both species from each other.

\section{Discussion}

Fermented dairy products are important in Africa as source of nutrients and as weaning food. Fermentation is an essential preservation method in the absence of refrigeration [67-69]. Analyses of dairy adaptations and potential 
Table 2 GenBank accession numbers and reference sequence numbers of strains used in this study

\begin{tabular}{|c|c|c|c|c|}
\hline Species & Strain & Source & $\begin{array}{l}\text { Genbank accession or } \\
\text { reference sequence number }\end{array}$ & Reference \\
\hline $\begin{array}{l}\text { artificial antibiotic } \\
\text { resistance genome }\end{array}$ & various & $\begin{array}{l}\text { gene sequences of published } \\
\text { antibiotic resistance genes }\end{array}$ & none & {$[37]$} \\
\hline Lactococcus lactis subsp. cremoris & MG1363 & $\begin{array}{l}\text { international prototype for } L A B \\
\text { genetics; plasmid-free descendant } \\
\text { of NCDO712, a cheese starter }\end{array}$ & [GenBank:NC_009004] & {$[38]$} \\
\hline S. agalactiae & $2603 \mathrm{~V} / \mathrm{R}$ & human clinical specimen & [GenBank:NC_004116] & {$[34]$} \\
\hline S. agalactiae & NEM316 & human clinical specimen & [GenBank:NC_004368] & {$[39]$} \\
\hline S. anginosus & 1_2_62CV & human clinical specimen & [GenBank:NZ_ADME00000000] & HMP a) \\
\hline S. bovis & ATCC 700338 & $\begin{array}{l}\text { human clinical specimen, } \\
\text { synovial fluid from knee }\end{array}$ & [GenBank:NZ_AEEL00000000] & HMP a) \\
\hline S. dysgalactiae subsp. equisimilis & GGS_124 & human clinical specimen & [GenBank:AP010935] & {$[40]$} \\
\hline S. equi subsp. equi & 4047 & horse clinical specimen & [GenBank:FM204883] & [41] \\
\hline S. equi subsp. zooepidemicus & MGCS10565 & human clinical specimen & [GenBank:CP001129] & {$[42]$} \\
\hline S. equinus & ATCC 9812 & human clinical specimen, gut & [GenBank: AEVB00000000] & $H M P^{a)}$ \\
\hline S. gallolyticus subsp. gallolyticus & ATCC 43143 & human clinical specimen, blood & [GenBank:AP012053] & {$[32]$} \\
\hline S. gallolyticus subsp. gallolyticus & ATCC BAA-2069 & human clinical specimen, blood & [GenBank:FR824043] & [33] \\
\hline S. gallolyticus subsp. gallolyticus & UCN34 & human clinical specimen, blood & [GenBank:FN597254] & [13] \\
\hline S. gallolyticus subsp. gallolyticus & TX20005 & human clinical specimen, heart & [GenBank:NZ_AEEM00000000] & HMP a) \\
\hline $\begin{array}{l}\text { S. gallolyticus subsp. macedonicus } \\
\text { (=S. macedonicus) }\end{array}$ & ACA-DC 198 & Greek kasseri cheese, dairy isolate & $\begin{array}{l}\text { [GenBank:HE613569] (genome) and } \\
\text { [GenBank:HE613570] (plasmid pSMA198) }\end{array}$ & {$[30,43,44]$} \\
\hline S. gallolyticus subsp. pasteurianus & ATCC 43144 & human clinical specimen, blood & [GenBank:AP012054] & {$[32]$} \\
\hline S. infantarius subsp. infantarius & $\begin{array}{l}\text { ATCC BAA-102 } \\
\text { (isogenetic strain } \\
\text { of CCUG } 43820^{\top} \text { ) }\end{array}$ & human infant, feces & [GenBank: ABJK00000000] & HMP a) \\
\hline S. infantarius subsp. infantarius & CJ18 & fermented camel milk suusac & $\begin{array}{l}\text { [GenBank:CP003295] (genome) } \\
\text { and [GenBank:CP003296] } \\
\text { (plasmid pSICJ18-1) }\end{array}$ & $\begin{array}{l}\text { this study } \\
\text { and }[2,7,31]\end{array}$ \\
\hline S. infantarius subsp. infantarius & LP90 & dairy origin & [GenBank:HM008642] & none \\
\hline S. mitis & B6 & hospital isolate Germany & [GenBank:NC_013853] & {$[45]$} \\
\hline S. pneumoniae & D39 (=NCTC 7466) & virulent human clinical isolate & [GenBank:NC_008533] & {$[36]$} \\
\hline S. pneumoniae & R6 (=ATCC BAA-255) & $\begin{array}{l}\text { unencapsulated, parent strain } \\
\text { R36A derived from D39 }\end{array}$ & [GenBank:NC_003098] & {$[46]$} \\
\hline S. pneumoniae & TIGR4 & human clinical isolate & [GenBank:NC_003028] & {$[47]$} \\
\hline S. pyogenes & M1 GAS (=SF370) & human clinical isolate & [GenBank:NC_002737] & {$[35]$} \\
\hline S. salivarius & ATCC 25975 & human saliva & [GenBank:AF389474] & {$[48]$} \\
\hline S. sanguinis & SK36 & human dental plaque & [GenBank:NC_009009] & {$[49]$} \\
\hline S. thermophilus & CNRZ1066 & yogurt & [GenBank:NC_006449] & {$[26]$} \\
\hline S. thermophilus & LMG18311 & yogurt & [GenBank:NC_006448] & {$[26]$} \\
\hline S. thermophilus & LMD-9 (=ATCC BAA-491) & yogurt & [GenBank:NC_008532] & {$[27]$} \\
\hline
\end{tabular}



virulence factors of bacteria leading spontaneous fermentation processes is therefore important to identify consumers' health risk potential and unravel novel fermentative lactic acid bacteria strains.

In this study, we report the complete genome sequence of the African dairy isolate Sii CJ18, the first complete assembled genome of a $S$. infantarius species. Whole genome comparison of Sii CJ18 to Sii ATCC BAA-102 ${ }^{\mathrm{T}}$ and related streptococci revealed substantial adaptations to the dairy environment in CJ18, paralleling that of $S$. thermophilus. However, our data indicates that genome decay of Sii CJ18 is in a less advanced state compared to S. thermophilus, since most biosynthesis pathways seem to be intact and the number of pseudogenes (4.9\%) is smaller than for S. thermophilus (10-19\%). This suggests that establishment of CJ18 in the dairy environment is more 
Table 3 Strains and plasmids used in this study

\begin{tabular}{|c|c|c|}
\hline Material & Relevant features $^{a}$ & Source \\
\hline \multicolumn{3}{|l|}{ Strains } \\
\hline \multicolumn{3}{|c|}{ Streptococcus infantarius subsp. infantarius } \\
\hline CJ18 & Wild type strain, suusac isolate & {$[2,7,31]$} \\
\hline CJ18/pVE6007 & CJ18 derivative carrying pVE6007, $\mathrm{Cm}^{\mathrm{R}}$ & this study \\
\hline CJ18DlacllC & $\begin{array}{l}\text { lacllC::pLFB1005, lacllC gene } \\
\text { disruption derivative of } C J 18, \mathrm{Em}^{R}\end{array}$ & this study \\
\hline CJ18 1 lacZ & $\begin{array}{l}\text { lacZ:: pLFB1006, lacZ gene disruption } \\
\text { derivative of CJ18, Em }\end{array}$ & this study \\
\hline CJ18Dlacs & $\begin{array}{l}\text { lacS:::pLFB1007, lacS gene disruption } \\
\text { derivative of CJ18, EmR }\end{array}$ & this study \\
\hline \multicolumn{3}{|c|}{ Lactococcus lactis } \\
\hline LL302 & $\begin{array}{l}\text { RepA }{ }^{+} \text {derivative of MG1363, } \\
\text { host for pORI28 }\end{array}$ & {$[51]$} \\
\hline \multicolumn{3}{|l|}{ Plasmids } \\
\hline pORI28 & $\begin{array}{l}\mathrm{Em}^{\mathrm{R}}, \mathrm{Ori}^{+}, \mathrm{RepA}^{-} \text {, pWV01 derivative, } \\
\text { vector for chromosomal insertions } \\
\text { in Gram-positive bacteria }\end{array}$ & [52] \\
\hline pVE6007 & $\begin{array}{l}\mathrm{Cm}^{\mathrm{R}} \text {, thermosensitive derivative of } \\
\text { pWV1, carrier plasmid for pORI28 }\end{array}$ & [53] \\
\hline pLFB1005 & $\begin{array}{l}\mathrm{Em}^{\mathrm{R}}, \text { pORI28 derivative containing } \\
\text { a } 939 \text {-bp internal fragment of lacllC. }\end{array}$ & this study \\
\hline pLFB1006 & $\begin{array}{l}\mathrm{Em}^{\mathrm{R}}, \mathrm{pOR} 228 \text { derivative containing an } \\
1177 \text {-bp internal fragment of lac } Z \text {. }\end{array}$ & this study \\
\hline pLFB1007 & $\begin{array}{l}\mathrm{Em}^{\mathrm{R}}, \text { pORI28 derivative containing a } \\
\text { 900-bp internal fragment of lacS. }\end{array}$ & this study \\
\hline
\end{tabular}

${ }^{\mathrm{a}} \mathrm{Cm}^{R}$ Chloramphenicol resistant; $\mathrm{Em}^{R}$ Erythromycin resistant. recent than $S$. thermophilus strains or S. gallolyticus subsp. macedonicus ACA-DC 198. Based on genome decay, the most recent common ancestor for $S$. thermophilus strains was estimated to have lived 3,000-30,000 years ago, which is approximately the duration of human dairy activity $[26,70]$. Camels, however, were introduced in East Africa only around 2,500 years ago [71-73], and the less advanced state of genome decay in CJ18 may be related to the later start of African camel milk fermentation.

Adaptation to the dairy environment in S. thermophilus consists of enhanced uptake of lactose and peptides and loss of other metabolic pathways. CJ18 displays a similar adaptation in the lactose metabolism through the transporter LacS and $\beta$-galactosidase LacZ. Truncation of either LacS or LacZ resulted in significant impaired growth on lactose, confirming the functionality of this acquired lactose utilization path. Neither the second LacS (Sinf_1514), present in both CJ18 and ATCC BAA-102 ${ }^{\mathrm{T}}$, nor the lactose PTS could take over lactose transport in the LacS KO strain. The integration of transposases in the corresponding lactose PTS gene cluster seems therefore a result of loss of essentiality after the acquirement of lacS and $l a c Z$. Moreover, a concurrent activity of both transporters potentially leads to misbalance in redox or phosphorylation status of the cell, and hence positive selection on truncation of the lactose PTS gene cluster might have even occurred after acquirement of LacSZ. The release of galactose into the growth medium shows that LacS in CJ18 functions as a highly efficient antiporter and the competitiveness of



B
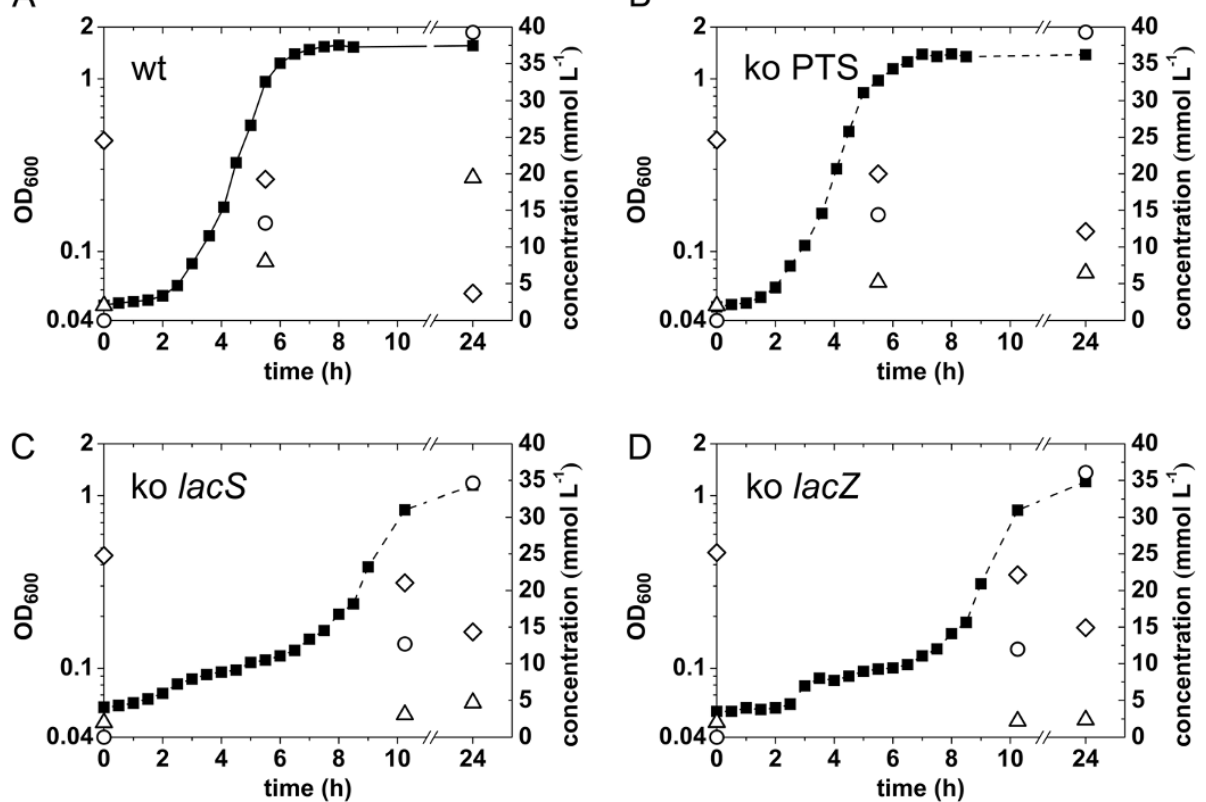

Figure 5 Growth kinetics of wild type and knock-out (KO) strains of Sii CJ18 in lactose medium. Growth kinetics of CJ18 wild type (A), CJ18 $/$ lacl/C (B), CJ184lacS (C) and CJ184lacZ (D) were compared in Elliker-based lactose medium for optical density $\left(\mathrm{OD}_{600} \mathbf{m}\right)$ and for metabolites lactose ( $($ ), lactate $(0)$ and galactose $(\Delta)$ in cell-free supernatant. Representative curves of two independent repetitions per strain are shown. 
CJ18 in the dairy environment seems therefore based on the acquired LacSZ. This facilitates efficient transport of lactose and as a consequence an increased lactose consumption and lactate production compared to ATCC BAA- $102^{\mathrm{T}}$ (isogenetic strain of CCUG $43820^{\mathrm{T}}$ ) [7].

The role of other adaptations to the dairy environment, such as the presence of a second oppABCDF operon and an extended EPS biosynthesis cluster is less clear. Enhanced uptake of casein derived peptides by the second peptide transporter could contribute to increased competiveness in milk. The enlarged cluster of Eps/Cpsrelated proteins could contribute to survival during the suusac back-slopping process, via improved biofilm formation capabilities. Furthermore, EPS contribute to texture of the fermented dairy product and the selection of strains for these textural properties might have occurred in the past $[18,26]$.

The more recent adaptation to the dairy environment of $\mathrm{C} 18$ is reflected by the lower number of pseudogenes and CRISPR spacers in CJ18 compared to S. thermophilus or S. gallolyticus subsp. macedonicus ACA-DC 198. CJ18 harbors nine CRISPR spacers whereas typical widespread dairy starter strains of $S$. thermophilus such as CNRZ 1066 and LMG 18311 harbor 42 and 39 spacers, respectively $[26,65]$. Phage infection and phage-related fermentation losses are major problems in dairy technology. The number of CRISPR spacer in a bacterial genome is directly linked to phage contact history and presumptive resistance against phages of that particular strain [74]. The African strain CJ18 was apparently not continuously exposed to phage infections over prolonged periods. This could be a result of the spontaneous nature of the traditional fermentation, which in contrast to industrial starter culture fermentations, does not rely on selected starter strains. The absence of CRISPR spacer identity between CJ18 and ATCC BAA $-102^{\mathrm{T}}$ further shows that the African CJ18 is only a distant relative of ATCC BAA- $102^{\mathrm{T}}$ as previously observed in microevolution of CRISPR spacers in other genera [75]. Additionally, the presence of 103 CDS in CJ18 shared only with other streptococci but not with ATCC BAA- $102^{\mathrm{T}}$ as well as the absence of $310 \mathrm{CDS}$ in CJ18 present in ATCC BAA- $102^{\mathrm{T}}$ indicates an ancestral streptococcal origin of these CDSs and again only distant relation between the two Sii strains.

Another interesting feature of CJ18 is its natural competence and DNA uptake capability, paralleling that of other streptococci and lactic acid bacteria (LAB) $[27,76]$. As a possible result of this, the genome displays traces of HGT events from commensal bacteria encountered in milk such as Lactococcus spp. and S. thermophilus but also pathogens like S. agalactiae. Furthermore, the natural competence could potentially contribute to the uptake of mobile genetic elements and to spread of antibiotic resistance genes [2]. Therefore the apparent intact competence machinery is probably of high importance for persistence of the strain in the African dairy environment.

CJ18 harbors none of the concerning typical streptococcal virulence factors [60] and less SBSEC-related virulence factors compared to e.g. S. gallolyticus and S. bovis. Moreover, most of these potential virulence factors are related to adhesion and not directly to infection, cytotoxicity or toxin production and are therefore of less concern. Many factors found in CJ18 are also present in the proclaimed safe strain S. gallolyticus subsp. macedonicus ACA-DC 198, a species without QPS-approval [25,77]. Some potential virulence factors or artifacts thereof were even found in S. thermophilus. Consequently, relying on genomic information alone, ingestion and digestion of large amounts of Sii via suusac does not seem to be a direct health risk for adults. However, the SBSEC-associated health risks for immune-deprived people, a major concern in Africa, and for children are less understood as epidemiological data on these diseases are not available. Furthermore, the uncertain association of Sii with human diseases necessitates further elucidation of presumptive Sii-specific virulence factors or the absence thereof in Sii.

\section{Conclusions}

We assembled and analyzed the first complete genome sequence of the species $S$. infantarius. The African dairy strain Sii CJ18 revealed many genetic adaptations to the dairy environment through acquired carbohydrate utilization pathways resulting in a lactose metabolism paralleling that of $S$. thermophilus. Potential mutations and insertions resulting in pseudogenes or truncated gene clusters indicate further evolution paralleling $S$. thermophilus. However, gene decay is not as advanced as in the dairy isolates $S$. thermophilus or S. gallolyticus subsp. macedonicus ACADC 198 and the establishment in the dairy environment is therefore likely from a younger evolutionary period.

The species $S$. infantarius harbors less virulence factors compared to the S. gallolyticus group. However, specific virulence factors for $S$. infantarius are not yet identified and epidemiological studies are necessary to prove the innocuity of African dairy Sii strains and milks predominantly fermented with these strains. This could prove traditional dairy fermentation in Africa as ideal process to enhance food safety and shelf life as well as the later application of Sii in an enhanced traditional fermentation technology paralleling the Western dairy industry, but specific for Africa. Conclusively, this study provides insight into the evolution of a novel dairy species and dairy environment in parallel to the Western counterpart.

\section{Methods}

\section{Bacterial strains and culture conditions}

Strains and plasmids used in this study are listed in Table 3. Lactococcus lactis LL302 was used as intermediate 
cloning host and cultured without agitation at $30^{\circ} \mathrm{C}$ in M17 (Biolife, Milan, Italy) [78], supplemented with 0.5\% glucose (G-M17). Sii strains were grown overnight in G$\mathrm{M} 17$ at $37^{\circ} \mathrm{C}$ for production of pre-cultures, or anaerobically on G-M17 plates at $37^{\circ} \mathrm{C}$.

For growth profiling on specific carbohydrates, a preculture of $\mathrm{Sii}$ in G-M17 was used to inoculate (1\% v/v) Elliker-based single carbohydrate medium [79,80], containing either glucose $(1 \%)$ or lactose $(1 \%)$. Growth profiling was performed in 125-mL butyl-rubber stoppered serum flasks [7] at $37^{\circ} \mathrm{C}$ for the determination of growth curves.

When appropriate, chloramphenicol and erythromycin were added to the media at a final concentration of $8 \mu \mathrm{g} \mathrm{mL}^{-1}$ and $10 \mu \mathrm{g} \mathrm{mL}^{-1}$, respectively. BHI agar media (Biolife) supplemented with $80 \mathrm{mg} \mathrm{mL}^{-1}$ 5-bromo-4-chlor3-indolyl-b-D-galactopyranoside (X-Gal, AppliChem, Darm stadt, Germany) and $0.5 \mathrm{mM}$ isopropyl-b-D-thiogalacto pyranosid (IPTG, AppliChem) was used to confirm phenotypes of KO strains. AnaeroGen packs (Oxoid, Pratteln, Switzerland) were used as oxygen scavengers for agar plate incubation in anaerobic jars. Stock cultures of all strains were stored at $-80^{\circ} \mathrm{C}$ in $30 \%$ glycerol (v/v). All chemicals and enzymes used in this study were obtained from SigmaAldrich (Buchs, Switzerland), unless stated otherwise.

\section{Genbank and reference sequence accession numbers}

The genome sequence and plasmid pSICJ18-1 of Sii CJ18 is available in the nucleotide database GenBank under the accession numbers [GenBank: CP003295, GenBank: CP003296] [31]. A summary of GenBank accession and reference sequence numbers of strains used in this study for bioinformatic analyses are provided in Table 2 .

\section{Electroporation of Sii CJ18 and Lactococcus lactis LL302}

Lc. lactis LL302 and Sii strains were transformed by electroporation using a procedure developed for Lc. lactis [81]. Positive transformants were selected on G-M17 agar media supplemented with chloramphenicol $\left(8 \mu \mathrm{g} \mathrm{mL}{ }^{-1}\right)$ or erythromycin $\left(10 \mu \mathrm{g} \mathrm{mL}^{-1}\right)$ as required after aerobic incubation at $30^{\circ} \mathrm{C}$ for $1-2$ days.

\section{DNA manipulations}

Molecular cloning and DNA manipulations were essentially performed as described by Sambrook et al. [82]. Plasmid DNA isolation from Lc. lactis LL302 was performed using an alkali cell lysis method after lysozyme treatment with subsequent purification [83] using a Midiprep Kit (Qiagen, Basel, Switzerland). Restriction enzymes and Phusion-polymerase were obtained from New England Biolabs (Frankfurt am Main, Germany) and T4-ligase from Invitrogen (Basel, Switzerland). Primers were purchased from Microsynth (Balgach, Switzerland).

\section{Construction of mutant strains}

For inactivation of the lactose PTS, the permease encoding lacIIBC gene (Sinf_0192) was disrupted using a single-cross-over strategy. A 959-bp internal fragment of lacIIC was amplified using a PCR master mix (Thermo Scientific, St. Leon-Rot, Germany), chromosomal DNA of CJ18 as template and the primers lacIIC_for and lacIIC_rev (Table 4). The obtained product was purified using a GFX purification column (GE Healthcare, Glattbrugg, Switzerland) and digested with BamHI and EcoRI (restriction sites introduced in primers). The restricted fragment (939 bp) was cloned into a BamHI/ EcoRI digested pORI28 resulting in pLFB1005, a lacIIBC disruption vector. Similarly, a 900-bp internal fragment of the lactose transporter gene lacS was amplified using primers lacS_for and lacS_rev. The product was purified, restricted with $B a m H I$ and EcoRI, and cloned into a BamHI/EcoRI digested pORI28, resulting in pLFB1007, a lacS interrupting vector.

For disruption of $l a c Z$, an 1177-bp internal fragment was amplified using primers lacZ_for and lacZ_rev. The product was digested with $B a m H I$ and Pst I and cloned into a similar digested pORI28, resulting in pLFB1006, a disruption vector for $l a c Z$.

The obtained plasmids were first transformed into $L c$. lactis LL302 for multiplication. After extraction, they were transformed into Sii CJ18 harboring the thermosensitive plasmid pVE6007 $\left(\mathrm{Cm}^{\mathrm{R}}\right)$ as carrier plasmid for pORI28 derivatives $\left(\mathrm{Em}^{\mathrm{R}}\right.$, Table 3$)$. Transformants were isolated on G-M17 supplemented with $10 \mu \mathrm{g} \mathrm{ml}^{-1}$ erythromycin at

Table 4 Oligonucleotides used to amplify internal fragments of target genes to construct knock-out strains

\begin{tabular}{|c|c|c|c|}
\hline Name & Sequence $\left(5^{\prime} \text { to } 3^{\prime}\right)^{a}$ & Name & Sequence $\left(5^{\prime}\right.$ to $\left.3^{\prime}\right)$ \\
\hline lacs_for & GATCGGATCCGATCCAAAGCAAAATAGTCA & lacS_con_for & TCCTATGCAGCGGGTGCTT \\
\hline lacs_rev & GATCGAATTCTGCAGTCAAGATAATTGGA & lacs_con_rev & GAGATAATCATAAGGATAACAA \\
\hline lacZ_for & GATCCTGCAGGCGTTAATACAGTTGACGCTCAC & lacZ_con_for & TTACTTAAACGATCCAAAGA \\
\hline lacZ_rev & GATCGGATCCTITGCCATGTACCGTGTGTT & lacZ_con_rev & CATGTTATTGGCACGATCCA \\
\hline lacllC_for & GATCGGATCCAATATTTGCGAGCGATTCGT & lacllC_con_for & GGAAACCATTCTTTGAGAG \\
\hline lacllC_rev & GATCGAATTCTACAATTGGAGCACCGAACA & lacllC_con_rev & ATTTGAAGATCCACACGTT \\
\hline pORI_for & TTG ATA ATG AAC TGT GCT GA & pORI_rev & ACG AAT CGC CAA CGT TाT CG \\
\hline
\end{tabular}

a) Endonuclease restriction sites introduced in primers are underlined. 
$30^{\circ} \mathrm{C}$. Growth of transformants at $37^{\circ} \mathrm{C}$ results in loss of pVE6007 and pORI28-derivatives cannot replicate anymore in the cells, forcing the plasmids to integrate into the chromosome. Therefore, colonies were picked, the presence of the correct plasmids confirmed by PCR and subsequently grown at $37^{\circ} \mathrm{C}$ in G-M17 supplemented with erythromycin for $24 \mathrm{~h}$. Primary integrants were then isolated on G-M17 supplemented with erythromycin. To check for the loss of pVE6007, colonies were picked and transferred to G-M17 plates with $10 \mu \mathrm{g} \mathrm{mL}^{-1}$ chloramphenicol and grown overnight at $30^{\circ} \mathrm{C}$. Colonies displaying an erythromycin resistant and chloramphenicol sensitive phenotype were checked for correct integration by PCR, using primers annealing outside of the region of integration in the chromosome (control primers in Table 4) and primers annealing in pORI28 (pORI28_for and pORI28_ rev). Integrants showing the correct phenotype and positive PCR analyses were streaked on G-M17 with erythromycin and a single colony isolate was checked again by PCR. Phenotypes of KO strains were confirmed using BHI/X-Gal/IPTG agar media.

\section{Metabolite analysis by HPLC}

Carbohydrate metabolites lactose, glucose, galactose, lactate and acetate were analyzed from bacterial culture supernatants on a Merck Hitachi HPLC system (Merck Hitachi, Darmstadt, Germany) as previously described [7].

\section{Genome annotation}

DNA isolation, sequencing and assembly of the genome of CJ18 was previously described [31]. Annotation of the assembled Sii CJ18 and metabolic reconstruction was performed on the RAST server [84]. The primary gene annotation by RAST was verified by comparing each RAST-predicted gene to the annotated genes of the species listed in Table 1. The genes were categorized into four groups: correct, possible frameshift, possible wrong start/stop assignment and non-conserved hypothetical. Each gene predicted by RAST plus 60-bp flanking regions were translated in silico and the three possible reading frames were compared to all annotated genes within genomes of related species (Table 1) using the SmithWaterman algorithm [85] on the basis of the BLOSUM62 substitution matrix. The score of the best match was compared to the self-alignment score of the original gene. If the highest score/self-alignment score-ratio was above 0.6 , the gene was categorized as correct. If one of the two alternative reading frames had a score ratio above 0.75 , the gene was assigned as having a possible frameshift. If the original gene was aligned to its best match with the number of either starting or ending gaps of more than 20-bp, it was categorized as possible wrong start/stop assignment. Genes with highest score/self-alignment scoreratios below 0.35 , or a Needleman-Wunsch-Alignment to its best match with a negative score, were assigned as nonconserved hypothetical. The prediction of the oriC region upstream of $d n a A$ was performed using Ori-finder [86].

\section{Phylogenetic analyses}

DNA sequences were retrieved from GenBank or sequenced in this study (Table 2). The following genes were used: groEL, gyrB, recA, recN, rpoB, secA, secY, sodA and $16 \mathrm{~S}$ rRNA encoding genes.

Sequences were aligned in MEGA4.0 [87] using the ClustalW algorithm and then trimmed to equal lengths. Construction of phylogenetic trees was performed in MEGA4.0 using the Neighbor-Joining method and a bootstrap test with 1000 repetitions followed by the computation of evolutionary distances using the Maximum Composite Likelihood method [87-90]. The resulting trees were rooted using Lactococcus lactis subsp. cremoris MG1363 as outgroup.

\section{Genome comparison - synteny plots}

The raw scores for the local alignment of all putative proteins of Sii CJ18 versus all proteins of the strains of interest (Table 2) were calculated using the Smith-Waterman algorithm [85] on the basis of the BLOSUM62 substitution matrix [91]. The score ratio is calculated by dividing the raw score by the score of the protein of interest aligned to itself. A threshold of 0.4 was used to distinguish between similar and non-similar proteins [92]. A synteny plot was created by plotting the genomic location of all proteins of Sii CJ18 on the X-axis and the genomic location of all similar proteins of the strain of interest on the Y-axis.

The available contigs of Sii ATCC BAA- $102^{\mathrm{T}}$ were putatively assembled using Projector 2 [93]. The contigs of Sii ATCC BAA- $102^{\mathrm{T}}$ were re-annotated through the RAST pipeline to facilitate highest comparability with the genome of CJ18 annotated also via the RAST pipeline [84].

\section{Construction of genome comparison graphs}

The Base Deviation Index (BDI) is calculated as the deviation of the base composition in a sliding $10-\mathrm{kb}$ window to the average base composition over the entire genome using the $X^{2}$ statistics [94]. The GC skew is calculated as $\frac{G-C}{G+C}$ with $G$ and $C$ being the number of guanin and cytosin in a sliding 1-kb window. The GC content is calculated as the percentage of guanin and cytosin in a sliding 1-kb window. Circular genome graphs were created using DNA Plotter [95].

\section{Search for bacteriocins}

The genomic sequence of Sii CJ18 was translated in silico in all three possible reading frames. All peptides available in the BAGEL2-Bacteriocin-Database [96] were searched in the translated sequences using the Smith-Waterman 
algorithm [85] on the basis of the BLOSUM62 substitution matrix [91]. High scoring matches were further evaluated by hand.

\section{CRISPR/Cas analysis}

CRISPRs were detected in the genomes of Sii CJ18 and ATCC BAA- $102^{\mathrm{T}}$ using CRISPRfinder and CRISPRdb $[97,98]$. Spacer sequences were aligned in BioEdit [99] through ClustalW after which DNA sequence identities were calculated. Amino acid sequences of CRISPR-associated (cas) proteins were analyzed analogous.

\section{Additional files}

Additional file 1: Complete table of CDS in Sii genome CJ18 in comparison with reference strain genomes. Description of data: This table contains all CDS of the African Sii genome CJ18 (excluding the plasmid) in comparison with reference strain genomes used in this study. A reverse comparison of CDS present in Sii ATCC BAA-102 ${ }^{\top}$ versus CJ18 is included. The CDS of the plasmid pSICJ18-1 are included in a separate tab with their highest NCBI Blast database gene match.

Additional file 2: Synteni plot of genome Sii CJ18 (x) vs. (A) S. gallolyticus subsp. macedonicus ACA-DC 198 (y), (B) S. gallolyticus subsp. gallolyticus UCN34 (y) and (C) S. gallolyticus subsp. gallolyticus ATCC BAA-2069 (y). Description of data: Similar to the genome of Sii ATCC BAA-102' ${ }^{\top}$, Sii CJ18 and S. gallolyticus strains ACA-DC 198, ATCC BAA-2069 and UCN34 display a high degree of conservation indicated by the alignment near the diagonal line. The same major insertion sites as in ATCC BAA-102 ${ }^{\top}$ can be identified as R4 (34.2 kb) consisting largely of phage-related genes; R6 (25.6 kb) encompassing a $13.2-\mathrm{kb}$ S. thermophilus-gene cluster comprising the additional gal-lac operon; and R9 (26.1 kb) containing among others an HTH-type transcriptional regulator rgg, primosomal protein $\mathrm{N}^{\prime}$ (replication factor $\mathrm{Y}$ ) superfamily II helicase and an FtsK/SpollIE family protein. The dairy isolate $S$. gallolyticus subsp. macedonicus ACA-DC 198 features an additional unique region $\mathrm{R} 12$ comprising bacteriocin-related structures of macedocin, salavaricin, lantibiotic modifying enzymes and transporters.

Additional file 3: Unique 13.2-kb gene locus with high DNA sequence identity to $S$. thermophilus in Sii genome CJ18. Description of data: The African Sii CJ18 harbors an approximately 13.2-kb insert of DNA with high sequence identity to S. thermophilus LMD-9 (white arrows) within a 25.6-kb insert (R6, Sinf_0915-Sinf_0939). The 18.4-kb gap between Sinf_0910 to Sinf_0928 was largely occupied with hypothetical proteins of unknown origin, few transporters and phage-related genes. Genes are not drawn to scale. Gene numbering corresponds to CDS region Sinf_0910-Sinf_0938. Black arrows indicate S. infantarius identity; grey other streptococci and white S. thermophilus identity.

Additional file 4: Phenotypes of $\mathrm{CJ} 18^{\mathrm{WT}}$ and mutant KO derivatives on BHI/X-Gal/IPTG agar media. Description of data: Confirmation of phenotypes of wild type, reference and KO strains on BHI/X-Gal/IPTG agar


white colonies for CJ18D/aCZ and CCUG 43820

Additional file 5: Growth kinetics of wild type and knock-out strains of Sii CJ18 in glucose medium. Description of data: Growth kinetics of CJ18 wild type (A), CJ184/aCIIC (B), CJ184lacS (C) and CJ184lacZ (D) were compared in Elliker-based glucose medium for optical density $\left(\mathrm{OD}_{600} \mathbf{\square}\right)$ and for metabolites glucose $(\nabla)$,lactate $(O)$ and galactose $(\Delta)$ in cell-free supernatant. Representative curves of two independent repetitions per strain are shown.

\section{Abbreviations}

CDS: Coding DNA sequence; CPS: Capsular polysaccharides;

CRISPR: Clustered regularly interspaced short palindromic repeats; EPS: Exopolysaccharides; KO: Knock-out; LAB: Lactic acid bacteria; PTS: Phosphotransferase system; QPS: Qualified presumption of safety;
SBSEC: Streptococcus bovis/Streptococcus equinus complex; Sii: Streptococcus infantarius subsp. infantarius.

\section{Competing interests}

The authors declare that they have no competing interests.

\section{Authors' contributions}

CJ performed genome assembly and analysis; RF performed bioinformatic analysis; MH performed construction of knock-out strains and experiments; $\mathrm{CL}$ and $\mathrm{LM}$ initiated and supervised the project; MJAS designed and supervised experiments and CJ, MJAS, LM and CL wrote/revised the paper. All authors have read and approved the final manuscript.

\section{Acknowledgements}

This study was funded by the UBS Optimus Foundation, Switzerland and the North South Centre at ETH Zurich, Switzerland.

The authors would like to thank Jan Kok, Department of Molecular Genetics, University of Groningen, for the gift of pORI28 and Lactococcus lactis LL302; and Emmanuelle Maguin, INRA Research Centre Jouy-en-Josas, for the gift of pVE6007.

Received: 23 July 2012 Accepted: 13 March 2013

Published: 22 March 2013

\section{References}

1. Herrera P, Min Kwon Y, Ricke SC: Ecology and pathogenicity of gastrointestinal Streptococcus bovis. Anaerobe 2009, 15:44-54.

2. Jans C, Bugnard J, Njage PMK, Lacroix C, Meile L: Lactic acid bacteria diversity of African raw and fermented camel milk products reveals a highly competitive, potentially health-threatening predominant microflora. LWT-Food Sci Technol 2012, 47:371-379.

3. Schlegel L, Grimont F, Ageron E, Grimont PAD, Bouvet A: Reappraisal of the taxonomy of the Streptococcus bovis/Streptococcus equinus complex and related species: description of Streptococcus gallolyticus subsp. gallolyticus subsp. nov., S. gallolyticus subsp. macedonicus subsp. nov. and S. gallolyticus subsp. pasteurianus subsp. nov. Int J Syst Evol Microbiol 2003, 53:631-645.

4. Schlegel L, Grimont F, Collins MD, Régnault B, Grimont PAD, Bouvet A: Streptococcus infantarius sp. nov., Streptococcus infantarius subsp. infantarius subsp. nov. and Streptococcus infantarius subsp. coli subsp. nov., isolated from humans and food. Int J Syst Evol Microbiol 2000, 50:1425-1434.

5. Wullschleger S, Lacroix C, Bonfoh B, Sissoko-Thiam A, Hugenschmidt S, Romanens E, Baumgartner S, Traoré I, Yaffee M, Jans C, Meile L: Analysis of lactic acid bacteria communities and their seasonal variations in a spontaneously fermented dairy product (Malian fènè) by applying a cultivation/genotype-based binary model. Int Dairy J 2013, 29:28-35.

6. Abdelgadir W, Nielsen DS, Hamad S, Jakobsen M: A traditional Sudanese fermented camel's milk product, Gariss, as a habitat of Streptococcus infantarius subsp. infantarius. Int J Food Microbiol 2008, 127:215-219.

7. Jans C, Gerber A, Bugnard J, Njage PMK, Lacroix C, Meile L: Novel Streptococcus infantarius subsp. infantarius variants harboring lactose metabolism genes homologous to Streptococcus thermophilus. Food Microbiol 2012, 31:33-42.

8. Díaz-Ruiz G, Guyot JP, Ruiz-Teran F, Morlon-Guyot J, Wacher C: Microbial and physiological characterization of weakly amylolytic but fast-growing lactic acid bacteria: a functional role in supporting microbial diversity in pozol, a Mexican fermented maize beverage. Appl Environ Microbiol 2003, 69:4367-4374.

9. Poyart C, Quesne G, Trieu-Cuot P: Taxonomic dissection of the Streptococcus bovis group by analysis of manganese-dependent superoxide dismutase gene $(\operatorname{sod} A)$ sequences: reclassification of 'Streptococcus infantarius subsp. coli' as Streptococcus lutetiensis sp. nov. and of Streptococcus bovis biotype II.2 as Streptococcus pasteurianus sp. nov. Int J Syst Evol Microbiol 2002, 52:1247-1255.

10. Beck M, Frodl R, Funke G: Comprehensive study of strains previously designated Streptococcus bovis consecutively isolated from human blood cultures and emended description of Streptococcus gallolyticus and Streptococcus infantarius subsp. coli. J Clin Microbiol 2008, 46:2966-2972.

11. Klein RS, Recco RA, Catalano MT, Edberg SC, Casey Jl, Steigbigel NH: Association of Streptococcus bovis with carcinoma of colon. New Engl J Med 1977, 297:800-802. 
12. Abdulamir AS, Hafidh RR, Abu Bakar F: Molecular detection, quantification, and isolation of Streptococcus gallolyticus bacteria colonizing colorectal tumors: inflammation-driven potential of carcinogenesis via IL-1, COX-2, and IL-8. Mol Cancer 2010, 9:249.

13. Rusniok C, Couvé E, Da Cunha V, El Gana R, Zidane N, Bouchier C, Poyart C, Leclercq R, Trieu-Cuot P, Glaser P: Genome sequence of Streptococcus gallolyticus: insights into its adaptation to the bovine rumen and its ability to cause endocarditis. J Bacteriol 2010, 192:2266-2276.

14. Sillanpää J, Nallapareddy SR, Qin X, Singh KV, Muzny DM, Kovar CL, Nazareth LV, Gibbs RA, Ferraro MJ, Steckelberg JM, Weinstock GM, Murray BE: A collagen-binding adhesin, Acb, and ten other putative MSCRAMM and pilus family proteins of Streptococcus gallolyticus subsp. gallolyticus (Streptococcus bovis group, biotype I). J Bacteriol 2009, 191:6643-6653.

15. Sillanpää J, Nallapareddy SR, Singh KV, Ferraro MJ, Murray BE: Adherence characteristics of endocarditis-derived Streptococcus gallolyticus ssp. gallolyticus (Streptococcus bovis biotype I) isolates to host extracellular matrix proteins. FEMS Microbiol Lett 2008, 289:104-109.

16. Vollmer T, Hinse D, Kleesiek K, Dreier J: Interactions between endocarditisderived Streptococcus gallolyticus subsp gallolyticus isolates and human endothelial cells. BMC Microbiol 2010, 10:78.

17. Hinse D, Vollmer T, Kleesiek K, Dreier J: Characterisation of Streptococcus gallolyticus subsp gallolyticus virulence factors. Int J Med Microbiol 2008, 298:64.

18. Monchois V, Willemot RM, Monsan P: Glucansucrases: mechanism of action and structure-function relationships. FEMS Microbiol Rev 1999, 23:131-151.

19. Shun CT, Lu SY, Yeh CY, Chiang CP, Chia JS, Chen JY: Glucosyltransferases of viridans streptococci are modulins of interleukin- 6 induction in infective endocarditis. Infect Immun 2005, 73:3261-3270.

20. Boleij A, Schaeps RMJ, de Kleijn S, Hermans PW, Glaser P, Pancholi V, Swinkels DW, Tjalsma H: Surface-exposed histone-like protein A modulates adherence of Streptococcus gallolyticus to colon adenocarcinoma cells. Infect Immun 2009, 77:5519-5527.

21. Hill C: Virulence or niche factors: what's in a name? J Bacteriol 2012, 194:5725-5727.

22. Corredoira J, Alonso MP, Coira A, Varela J: Association between Streptococcus infantarius (formerly S. bovis II/I) bacteremia and noncolonic cancer. J Clin Microbiol 2008, 46:1570.

23. Biarc J, Nguyen IS, Pini A, Gossé F, Richert S, Thiersé D, Van Dorsselaer A, Leize-Wagner E, Raul F, Klein JP, Schöller-Guinard M: Carcinogenic properties of proteins with pro-inflammatory activity from Streptococcus infantarius (formerly S. bovis). Carcinogenesis 2004, 25:1477-1484.

24. Boleij A, Muytjens CMJ, Bukhari SI, Cayet N, Glaser P, Hermans PWM, Swinkels DW, Bolhuis A, Tjalsma H: Novel clues on the specific association of Streptococcus gallolyticus subsp gallolyticus with colorectal cancer. J Infect Dis 2011, 203:1101-1109.

25. Leuschner RGK, Robinson TP, Hugas M, Cocconcelli PS, Richard-Forget F, Klein G, Licht TR, Nguyen-The C, Querol A, Richardson M, Suarez JE, Thrane $U$, Vlak JM, von Wright A: Qualified presumption of safety (QPS): a generic risk assessment approach for biological agents notified to the european food safety authority (EFSA). Trends Food Sci Technol 2010, 21:425-435.

26. Bolotin A, Quinquis B, Renault P, Sorokin A, Ehrlich SD, Kulakauskas S, Lapidus A, Goltsman E, Mazur M, Pusch GD, Fonstein M, Overbeek R, Kyprides N, Purnelle B, Prozzi D, Ngui K, Masuy D, Hancy F, Burteau S, Boutry M, Delcour J, Goffeau A, Hols P: Complete sequence and comparative genome analysis of the dairy bacterium Streptococcus thermophilus. Nat Biotechnol 2004, 22:1554-1558.

27. Makarova $\mathrm{K}$, et al: Comparative genomics of the lactic acid bacteria. Proc Natl Acad Sci U S A 2006, 103:15611-15616.

28. Hols P, Hancy F, Fontaine L, Grossiord B, Prozzi D, Leblond-Bourget N, Decaris B, Bolotin A, Delorme C, Ehrlich SD, Guédon E, Monnet W, Renault $P$, Kleerebezem M: New insights in the molecular biology and physiology of Streptococcus thermophilus revealed by comparative genomics. FEMS Microbiol Rev 2005, 29:435-463.

29. Kilpper-Bälz R, Fischer G, Schleifer KH: Nucleic acid hybridization of group N and group D streptococci. Curr Microbiol 1982, 7:245-250.

30. Papadimitriou K, Ferreira S, Papandreou NC, Mavrogonatou E, Supply P, Pot $B$, Tsakalidou E: Complete genome sequence of the dairy isolate Streptococcus macedonicus ACA-DC 198. J Bacteriol 2012, 194:1838.

31. Jans C, Follador R, Lacroix C, Meile L, Stevens MJA: Complete genome sequence of the African dairy isolate Streptococcus infantarius subsp. infantarius strain CJ18. J Bacteriol 2012, 194:2105-2106.
32. Lin IH, Liu T-T, Teng Y-T, Wu H-L, Liu Y-M, Wu K-M, Chang C-H, Hsu M-T: Sequencing and comparative genome analysis of two pathogenic Streptococcus gallolyticus subspecies: genome plasticity, adaptation and virulence. PLoS One 2011, 6:e20519.

33. Hinse D, Vollmer T, Rückert C, Blom J, Kalinowski J, Knabbe C, Dreier J: Complete genome and comparative analysis of Streptococcus gallolyticus subsp gallolyticus, an emerging pathogen of infective endocarditis. BMC Genomics 2011, 12:400.

34. Tettelin $\mathrm{H}$, et al: Complete genome sequence and comparative genomic analysis of an emerging human pathogen, serotype V Streptococcus agalactiae. Proc Natl Acad Sci U S A 2002, 99:12391-12396.

35. Ferretti JJ, McShan WM, Ajdic D, Savic DJ, Savic G, Lyon K, Primeaux C, Sezate S, Suvorov AN, Kenton S, Lai HS, Lin SP, Qian YD, Jia HG, Najar FZ, Ren Q, Zhu H, Song L, White J, Yuan XL, Clifton SW, Roe BA, McLaughlin R: Complete genome sequence of an M1 strain of Streptococcus pyogenes. Proc Natl Acad Sci U S A 2001, 98:4658-4663.

36. Lanie JA, Ng W-LN, Kazmierczak KM, Andrzejewski TM, Davidsen TM, Wayne KJ, Tettelin H, Glass JI, Winkler ME: Genome sequence of Avery's virulent serotype 2 strain D39 of Streptococcus pneumoniae and comparison with that of unencapsulated laboratory strain R6. J Bacterio/ 2007, 189:38-51.

37. Bennedsen M, Stuer-Lauridsen B, Danielsen M, Johansen E: Screening for antimicrobial resistance genes and virulence factors via genome sequencing. Appl Environ Microbiol 2011, 77:2785-2787.

38. Wegmann U, O'Connell-Motherway M, Zomer A, Buist G, Shearman C, Canchaya C, Ventura M, Goesmann A, Gasson MJ, Kuipers OP, van Sinderen $D$, Kok J: Complete genome sequence of the prototype lactic acid bacterium Lactococcus lactis subsp. cremoris MG1363. J Bacteriol 2007, 189:3256-3270.

39. Sitkiewicz I, Green NM, Guo N, Bongiovanni AM, Witkin SS, Musser JM: Transcriptome adaptation of group B Streptococcus to growth in human amniotic fluid. PLoS One 2009, 4:e6114.

40. Shimomura Y, Okumura K, Murayama SY, Yagi J, Ubukata K, Kirikae T, Miyoshi-Akiyama T: Complete genome sequencing and analysis of a Lancefield group G Streptococcus dysgalactiae subsp. equisimilis strain causing streptococcal toxic shock syndrome (STSS). BMC Genomics 2011, 12:17.

41. Holden MTG, et al: Rapid evolution of virulence and drug resistance in the emerging zoonotic pathogen Streptococcus suis. PLoS One 2009, 4:e6072.

42. Beres SB, Sesso R, Pinto SWL, Hoe NP, Porcella SF, DeLeo FR, Musser JM: Genome sequence of a Lancefield group C Streptococcus zooepidemicus strain causing epidemic nephritis: new information about an old disease. PLoS One 2008, 3:e3026.

43. Georgalaki MD, Van den Berghe E, Kritikos D, Devreese B, Van Beeumen J, Kalantzopoulos G, De Vuyst L, Tsakalidou E: Macedocin, a food grade lantibiotic produced by Streptococcus macedonicus ACA-DC 198. Appl Environ Microbiol 2002, 68:5891-5903.

44. Tsakalidou E, Zoidou E, Pot B, Wassill L, Ludwig W, Devriese LA, Kalantzopoulos G, Schleifer KH, Kersters K: Identification of streptococci from Greek Kasseri cheese and description of Streptococcus macedonicus sp. nov. Int J Syst Bacteriol 1998, 48:519-527.

45. Denapaite $D$, Brückner R, Nuhn M, Reichmann P, Henrich B, Maurer $P$, Schähle Y, Selbmann P, Zimmermann W, Wambutt R, Hakenbeck R: The genome of Streptococcus mitis B6 - what is a commensal? PLoS One 2010, 5:e9426.

46. Hoskins J, et al: Genome of the bacterium Streptococcus pneumoniae strain R6. J Bacterio/ 2001, 183:5709-5717.

47. Tettelin $\mathrm{H}$, et al: Complete genome sequence of a virulent isolate of Streptococcus pneumoniae. Science 2001, 293:498-506.

48. Vaillancourt K, Moineau S, Frenette M, Lessard C, Vadeboncoeur C: Galactose and lactose genes from the galactose-positive bacterium Streptococcus salivarius and the phylogenetically related galactosenegative bacterium Streptococcus thermophilus: organization, sequence, transcription, and activity of the gal gene products. J Bacteriol 2002, 184:785-793.

49. Xu P, Alves JM, Kitten T, Brown A, Chen ZM, Ozaki LS, Manque P, Ge XC, Serrano MG, Puiu D, Hendricks S, Wang YP, Chaplin MD, Akan D, Paik S, Peterson DL, Macrina FL, Buck GA: Genome of the opportunistic pathogen Streptococcus sanguinis. J Bacterio/ 2007, 189:3166-3175.

50. Zoetendal EG, Raes J, van den Bogert B, Arumugam M, Booijink CCGM, Troost FJ, Bork P, Wels M, de Vos WM, Kleerebezem M: The human small intestinal microbiota is driven by rapid uptake and conversion of simple carbohydrates. ISME J 2012, 6:1415-1426. 
51. Leenhouts K, Bolhuis A, Venema G, Kok J: Construction of a food-grade multiple-copy integration system for Lactococcus lactis. Appl Microbiol Biotechnol 1998, 49:417-423.

52. Leenhouts K, Venema G: Lactococcal plasmid vectors. In Plasmids: a practical approach. 2nd edition. Edited by Hardy KG. Oxford, UK: IRL Press, Inc; 1993:65-94.

53. Maguin E, Duwat $P$, Hege T, Ehrlich D, Gruss A: New thermosensitive plasmid for Gram-positive bacteria. J Bacteriol 1992, 174:5633-5638.

54. Monnet V: Bacterial oligopeptide-binding proteins. Cell Mol Life Sci 2003, 60:2100-2114

55. Garault $P$, Le Bars D, Besset C, Monnet V: Three oligopeptide-binding proteins are involved in the oligopeptide transport of Streptococcus thermophilus. J Biol Chem 2002, 277:32-39.

56. Smith HE, Damman M, van der Velde J, Wagenaar F, Wisselink HJ, Stockhofe-Zurwieden N, Smits MA: Identification and characterization of the cps locus of Streptococcus suis serotype 2: the capsule protects against phagocytosis and is an important virulence factor. Infect Immun 1999, 67:1750-1756.

57. Loesche WJ: Role of Streptococcus mutans in human dental decay. Microbiol Rev 1986, 50:353-380.

58. Sperisen P, Schmid CD, Bucher P, Zilian O: Stealth proteins: in silico identification of a novel protein family rendering bacterial pathogens invisible to host immune defense. PLoS Comp Biol 2005, 1:492-499.

59. Cleary P, Cheng Q: Medically important beta-hemolytic streptococci. In The Prokaryotes, an evolving electronic resource for the microbiological community. Edited by Dworkin M, Falkow S, Rosenberg E, Schleifer K-H, Stackebrandt E. New York, NY, USA: Springer Verlag; 2006:108-148.

60. Yang J, Chen LH, Sun LL, Yu J, Jin Q: VFDB 2008 release: an enhanced web-based resource for comparative pathogenomics. Nucleic Acids Res 2008, 36:D539-D542.

61. Burton B, Dubnau D: Membrane-associated DNA transport machines. Cold Spring Harb Perspect Biol 2010, 2:a000406.

62. Claverys JP, Martin B, Polard P: The genetic transformation machinery: composition, localization, and mechanism. FEMS Microbiol Rev 2009, 33:643-656

63. Mashburn-Warren L, Morrison DA, Federle MJ: A novel double-tryptophan peptide pheromone controls competence in Streptococcus spp. via an Rgg regulator. Mol Microbiol 2010, 78:589-606.

64. Al-Attar S, Westra ER, van der Oost J, Brouns SJJ: Clustered regularly interspaced short palindromic repeats (CRISPRs): the hallmark of an ingenious antiviral defense mechanism in prokaryotes. Biol Chem 2011, 392:277-289.

65. Horvath P, Romero DA, Coute-Monvoisin AC, Richards M, Deveau H, Moineau S, Boyaval P, Fremaux C, Barrangou R: Diversity, activity, and evolution of CRISPR loci in Streptococcus thermophilus. J Bacteriol 2008, 190:1401-1412.

66. Nes IF, Diep DB, Holo H: Bacteriocin diversity in Streptococcus and Enterococcus. J Bacteriol 2007, 189:1189-1198.

67. Holzapfel W: Use of starter cultures in fermentation on a household scale. Food Control 1997, 8:241-258.

68. Motarjemi Y, Käferstein F, Moy G, Quevedo F: Contaminated weaning food: a major risk factor for diarrhea and associated malnutrition. Bull WHO 1993, 71:79-92.

69. Oyewole OB: Lactic fermented foods in Africa and their benefits. Food Control 1997, 8:289-297.

70. Fox PF: Cheese: chemistry, physics and microbiology. London, UK: Chapman \& Hall; 1993.

71. Epstein H: The origin of domestic animals of Africa. Volume I and II. New York, NY, USA: Africana Publ. Corp; 1971.

72. Bulliet RW: The camel and the wheel. Cambridge, MA, USA: Harvard University Press; 1975.

73. Mikesell MW: Notes on the dispersal of the dromedary. Southwest J Anthrop 1955, 11:231-245.

74. Mills S, Griffin C, Coffey A, Meijer WC, Hafkamp B, Ross RP: CRISPR analysis of bacteriophage-insensitive mutants (BIMs) of industrial Streptococcus thermophilus- implications for starter design. J Appl Microbiol 2010, 108:945-955.

75. Cui YJ, Li YJ, Gorgé O, Platonov ME, Yan YF, Guo ZB, Pourcel C, Dentovskaya SV, Balakhonov SV, Wang XY, Song YJ, Anisimov AP, Vergnaud G, Yang RF: Insight into microevolution of Yersinia pestis by clustered regularly interspaced short palindromic repeats. PLoS One 2008, 3:e2652.
76. Delorme C, Poyart C, Ehrlich SD, Renault P: Extent of horizontal gene transfer in evolution of streptococci of the salivarius group. J Bacteriol 2007, 189:1330-1341.

77. Maragkoudakis PA, Papadelli M, Georgalaki M, Panayotopoulou EG, Martinez-Gonzalez B, Mentis AF, Petraki K, Sgouras DN, Tsakalidou E: In vitro and in vivo safety evaluation of the bacteriocin producer Streptococcus macedonicus ACA-DC 198. Int J Food Microbiol 2009, 133:141-147.

78. Terzaghi BE, Sandine WE: Improved medium for lactic streptococci and their bacteriophages. Appl Microbiol 1975, 29:807-813.

79. Elliker PR, Anderson AW, Hannesson G: An agar culture medium for lactic acid streptococci and lactobacilli. J Dairy Sci 1956, 39:1611-1612.

80. Lee R, Molsknes T, Sandine WE, Elliker PR: Carbohydrate metabolism in lactic streptococci: fate of galactose supplied in free or disaccharide form. Appl Microbiol 1973, 26:951-958.

81. Holo H, Nes IF: Transformation of Lactococcus by electroporation. In Methods in Molecular Biology; Electroporation protocols for microorganisms. Volume 47. Edited by Nickoloff JA.; 1995:195-199.

82. Sambrook J, Russel DW: Molecular Cloning: a laboratory manual. 3rd edition. New York: Cold Spring Harbor Laboratory Press; 2001.

83. Birnboim HC, Doly J: Rapid alkaline extraction procedure for screening recombinant plasmid DNA. Nucleic Acids Res 1979, 7:1513-1523.

84. Aziz RK, Bartels D, Best AA, DeJongh M, Disz T, Edwards RA, Formsma K, Gerdes S, Glass EM, Kubal M, Meyer F, Olsen GJ, Olson R, Osterman AL, Overbeek RA, McNeil LK, Paarmann D, Paczian T, Parrello B, Pusch GD, Reich C, Stevens R, Vassieva O, Vonstein V, Wilke A, Zagnitko O: The RAST server: rapid annotations using subsystems technology. BMC Genomics 2008, 9:75.

85. Smith TF, Waterman MS: Identification of common molecular subsequences. J Mol Biol 1981, 147:195-197.

86. Gao F, Zhang CT: Ori-Finder: a web-based system for finding oriCs in unannotated bacterial genomes. BMC Bioinformatics 2008, 9:79.

87. Tamura K, Dudley J, Nei M, Kumar S: MEGA4: Molecular evolutionary genetics analysis (MEGA) software version 4.0. Mol Biol Evol 2007, 24:1596-1599.

88. Felsenstein J: Confidence limits on phylogenies: an approach using the bootstrap. Evolution 1985, 39:783-791.

89. Saitou N, Nei M: The neighbor-joining method: a new method for reconstructing phylogenetic trees. Mol Biol Evol 1987, 4:406-425.

90. Tamura K, Nei M, Kumar S: Prospects for inferring very large phylogenies by using the neighbor-joining method. Proc Natl Acad Sci U S A 2004, 101:11030-11035

91. Henikoff S, Henikoff JG: Amino acid substitution matrices from protein blocks. Proc Natl Acad Sci U S A 1992, 89:10915-10919.

92. Rasko DA, Myers GSA, Ravel J: Visualization of comparative genomic analyses by BLAST score ratio. BMC Bioinformatics 2005, 6:2.

93. van Hijum S, Zomer AL, Kuipers OP, Kok J: Projector 2: contig mapping for efficient gap-closure of prokaryotic genome sequence assemblies. Nucleic Acids Res 2005, 33:W560-W566.

94. Molenaar D, Bringel F, Schuren FH, de Vos WM, Siezen RJ, Kleerebezem M: Exploring Lactobacillus plantarum genome diversity by using microarrays. J Bacteriol 2005, 187:6119-6127.

95. Carver T, Thomson N, Bleasby A, Berriman M, Parkhill J: DNAPlotter: circular and linear interactive genome visualization. Bioinformatics 2009, 25:119-120.

96. de Jong A, van Heel AJ, Kok J, Kuipers OP: BAGEL2: mining for bacteriocins in genomic data. Nucleic Acids Res 2010, 38:W647-W651.

97. Grissa I, Vergnaud G, Pourcel C: CRISPRFinder: a web tool to identify clustered regularly interspaced short palindromic repeats. Nucleic Acids Res 2007, 35:W52-W57.

98. Grissa I, Vergnaud G, Pourcel C: The CRISPRdb database and tools to display CRISPRs and to generate dictionaries of spacers and repeats. BMC Bioinformatics 2007, 8:172.

99. Hall TA: BioEdit: a user-friendly biological sequence alignment editor and analysis program for Windows 95/98/NT. Nucl Acids Symp Ser 1999, 41:95-98.

doi:10.1186/1471-2164-14-200

Cite this article as: Jans et al:: Comparative genome analysis of Streptococcus infantarius subsp. infantarius CJ18, an African fermented camel milk isolate with adaptations to dairy environment. BMC Genomics 2013 14:200. 